\title{
Energy balance \& greenhouse gas emissions of dryland camelina as influenced by tillage and nitrogen
}

\section{Authors: Reza Keshavarz-Afshar, Yesuf Assen Mohammed, \& Chengci Chen}

This is a postprint of an article that originally appeared in Energy in November 2015.

Keshavarz-Afshar, Reza, Yesuf Assen Mohammed, and Chengci Chen. "Energy balance \& greenhouse gas emissions of dryland camelina as influenced by tillage and nitrogen." Energy 91 (November 2015): 1057-1063. https://dx.doi.org/10.1016/j.energy.2015.07.136.

Made available through Montana State University's $\underline{\text { ScholarWorks }}$ 


\title{
Energy balance \& greenhouse gas emissions of dryland camelina as influenced by tillage and nitrogen
}

\author{
Reza Keshavarz-Afshar, Yesuf Assen Mohammed, Chengci Chen \\ Eastern Agricultural Research Center, Montana State University, 1501 N Central Ave., Sidney, MT 59270, USA
}

\begin{abstract}
Despite the great potential of camelina (Camelina sativa L. Crantz) as a promising biofuel feedstock, in-farm energy flow of the crop and its associated environmental impacts has not received sufficient attention from researchers. In order to assess net energy gain and to identify energy saving and environmental friendly production operations, a two year study was conducted at central Montana. We investigated the effects of tillage method (CT (conventional tillage) vs. NT (no-tillage)) and N (nitrogen) fertilizer rate $(0,45,90 \mathrm{~kg} \mathrm{~N}$ ha-1) on energy balance and GHG (greenhouse gas emission) of dryland camelina production. Results indicated that energy input and GHG emission were 5 and 8\% lower in NT than in CT. Application of 45 and $90 \mathrm{~kg} \mathrm{~N}$ ha-1 increased camelina energy input by 186 and 365\%, while increased energy output by only 21 and $64 \%$, respectively. There was no significant difference in net energy gain in response to $\mathrm{N}$ fertilization, but lower energy efficiency in response to higher $\mathrm{N}$ inputs. Averaged across tillage systems, the GHG emission was $32.0 \mathrm{~kg} \mathrm{C}$ eq ha-1 with $0 \mathrm{~N}$ applied, and the GHG emission increased by 206 and $389 \%$ when 45 and $90 \mathrm{~kg} \mathrm{~N}$ ha-1 was applied. Overall, $\mathrm{N}$ fertilizer had the biggest share in total energy input. Averaged over all experimental treatments, 14,945 MJ ha-1 net energy was obtained from camelina crop in this study which shows the potential of this crop as a bioenergy feedstock. Our result showed that implementation of $\mathrm{NT}$ is strongly recommendable for camelina production in this region. Moreover, improvement of $\mathrm{N}$ use efficiency has the highest priority to improve energy performance and reduce GHG emissions in camelina production.
\end{abstract}

\section{Introduction}

Bioenergy crops have great potential to replace the fallow in the predominant fallow-wheat (Triticum aestivum) cropping systems in the U.S. NGP (Northern Great Plains) [1]. Only a few bioenergy crops, however, fit the environmental boundaries and restrictions of this region [2]. Camelina is an annual oilseed crop with $32-43 \%$ (w/w) oil content [3]. Due to its favorable agronomic features, including short growing season, drought resistant characteristics, and low-input requirements (e.g. fertilizers and pesticides), camelina has became an attractive bio-feedstock for the NGP [4]. It is assumed that camelina, which is not currently approved as an edible oil in the U.S., can be successfully grown for advanced biofuel production on marginal lands of the NGP and/or as a rotation crop on fallow land; while decreasing concern about the "food versus fuel" issue [1].
Exceptional fatty acid profile containing high levels of alphalinolenic acid, cholesterol, and eicosenoic acid makes camelina an outstanding biofueld feedstock [3]. Several scenarios are now being considered for camelina as an energy crop for advanced biofuel production. In all scenarios camelina biodiesel was found to have lower emissions than diesel fuel. Camelina biodiesel even outperformed the traditional biodiesel crops (soybeans and canola) when land use change emissions were considered [5]. Li and Mupondwa [6] also reported less energy requirement and lower GHG emissions associated with camelina derived fuel production compared to other oilseed derived fuels and petroleum fuel. All these make camelina derived fuel environmentally attractive.

Despite the favorable agronomic features of camelina crop and the environmental attraction of cemelina derived fuel, the energy balance and GHG emission of producing this crop have not been evaluated sufficiently. In our previous studies, agronomic [2] and energetic [7] advantages of camelina-winter wheat rotation compared with fallow-winter wheat rotation in central Montana were reported. It has been concluded that optimization of 
agronomic practices is necessary to improve energy efficiency of camelina production in this semi-arid environment [7].

Optimization of the production practices, including tillage and fertilization could enhance the energy and economic performance of camelina thus improves the sustainability of camelina biofeedstock production. Although camelina is known as a crop with low input requirements [3], nitrogen fertilization plays a vital role in camelina growth and seed formation [8] whereas the optimal $\mathrm{N}$ input level for best net energy gain and minimal environmental impact have not been established. Since production of nitrogen fertilizer requires large quantities of non-renewable energy, nitrogen represents the largest component of energy consumption among all inputs used in most agricultural systems [9]. The share of nitrogen fertilizer in total energy input has been reported in a range of $40-55 \%$ in most cropping systems of the developed countries [10]. McLaughlin et al. [9] reported that the indirect energy requirement for the manufacture of inorganic fertilizers and their application in the field represented the single largest energy input (40-50\% of the total energy input) in NT grain-corn in Canada. Rathke and Diepenbrock [11] found 21-51\% share of nitrogen fertilizer in total energy input of oilseed rape production when 80 and $240 \mathrm{~kg} \mathrm{~N} \mathrm{ha}^{-1}$ was applied, respectively. Keshavarz-Afshar and Chen [7] reported $70 \%$ share of nitrogen fertilizer in total energy input of camelina in central Montana. Optimization of nitrogen fertilization, therefore, will highly influence the energy balance of camelina.

Soil preparation and tillage is another high energy-demanding operation in crop production systems [12]. Borin et al. [13] estimated that $30 \%$ of energy used in the field is attributed to tillage. Thus, implementation of conservation tillage practices, such as MT (minimum tillage) and NT, is expected to reduce the consumption of non-renewable energy inputs, which in turn will improve the overall energy use efficiency [14]. Šarauskis et al. [15] reported 12-58\% and Bonari et al. [16] reported 55\% less fuel consumption in conservation tillage practices compared to $\mathrm{CT}$ (conventional tillage) without any negative influence on crop yield. Hernanz et al. [12] reported that adoption of MT and NT in monoculture cereal and cereal-fallow rotation in central Spain resulted in 11 and 14\% energy saving, respectively. They also reported 15 and 19\% higher energy productivity in NT and MT compared with CT in each crop rotation. Most long-term field experiments demonstrated that NT and CT produced comparable yields (thus energy outputs). Cantero-Martínez et al. [17] reported that in two locations out of three in semiarid regions of Spain, NT barley produced 4 and 13\% greater yield than MT and 9 and 14\% greater yield than CT. López-Bellido et al. [18] evaluated the effect of NT and CT on wheat yield in a wheat-chickpea rotation under rain-fed Mediterranean conditions. They found no significant influence of the tillage system on wheat yield in three years of the study. In another study, LópezBellido et al. [19] concluded that continuous NT may represent an economically and environmentally viable alternative to conventional tillage for sunflower production under rain-fed Mediterranean conditions.

Optimization of the agronomic practices will not only improve energy efficiency, but also affect GHG emissions of the biofeedstock production, thereby affecting the sustainability of the farming system [20]. The current policies within agriculture seek to develop crop production systems that minimize fossil energy consumption and minimize GHG emissions without deleterious effects on energy output [21]. Understanding the GHG emissions associated with different agronomic practices, such as tillage and fertilization, is helpful to identify C-efficient alternatives [22].

Since camelina is a relatively new crop to the United States, energy performance of this crop and its associated GHG emissions under different production practices has not been well studied. The objective of this study was to determine how tillage method and $\mathrm{N}$ fertilizer rate influence energy balance and GHG emissions of camelina in a dryland farming system of central Montana.

\section{Materials and methods}

To evaluate the effects of tillage method (CT and NT) and N fertilizer rate $\left(0,45,90 \mathrm{~kg} \mathrm{~N}^{-1}\right)$ on energy balance and GHG emissions of camelina production, a two-year field study (2013-2014) was conducted at the Central Agricultural Research Center $\left(47^{\circ} 03^{\prime} \mathrm{N}, 109^{\circ} 57^{\prime} \mathrm{W}\right.$; $1400 \mathrm{~m}$ elevation) near Moccasin, Montana. The soil at the site is classified as a Judith clay loam (fineloamy, carbonatic, frigid Typic Calciustolls) and its water holding capacity is limited by gravel content and shallow soil profile. Long term (1909-2013) average crop year (September to August) precipitation in this area is about $390 \mathrm{~mm}$ with mean air temperature of about $5.8{ }^{\circ} \mathrm{C}$. Table 1 presents the monthly precipitation and average temperature during the study and the 20-yr long-term averages.

\subsection{Experimental design and treatments}

The experiment layout was split-plot based on a randomized complete block design with four replicates. Tillage was assigned to the main plots and nitrogen treatments were allocated to the subplots. Individual subplots were $15.2 \mathrm{~m}$ long and $3.7 \mathrm{~m}$ wide. In both years, camelina was planted following wheat. Conventional tillage consisted of two passes of a sweep cultivator, while in NT system seeds were sown directly into wheat stubble.

In both tillage systems, camelina was planted in late March to early April using a NT air-seeder at the rate of $3.4 \mathrm{~kg}$ seed ha ${ }^{-1}$ with $30-\mathrm{cm}$ row spacing. Based on our previous experiences, no $\mathrm{P}$ (phosphorus), K (potassium), and S (sulfur) fertilizers were applied since $\mathrm{P}, \mathrm{K}$, and $\mathrm{S}$ carried over from the previous crop supplied camelina requirements. Respective plots received 0,45 , and $90 \mathrm{~kg} \mathrm{~N} \mathrm{ha}^{-1}$ which was broadcasted in the form of urea $(46 \% \mathrm{~N})$ at the end of rosette stage.

Weed management differed between tillage systems. In NT system, glyphosate (N-[phosphonomethyl] glycine) was sprayed once in the fall. In CT system, however, no herbicide was used in the fall and weeds were controlled by tillage (sweep cultivator). Both $\mathrm{NT}$ and $\mathrm{CT}$ systems received a glyphosate (N-[phosphonomethyl] glycine) application in the spring prior to seeding camelina (both at the rate of $1.12 \mathrm{~L}$ active ingredient $\mathrm{ha}^{-1}$ ).

Table 1

Monthly precipitation and average air temperature during the study and long term average at Moccasin, Montana.

\begin{tabular}{lrrlllll}
\hline & \multicolumn{3}{c}{ Rainfall $(\mathrm{mm})$} & & \multicolumn{3}{c}{ Air temperature $\left({ }^{\circ} \mathrm{C}\right)$} \\
\cline { 2 - 3 } Month & 2013 & 2014 & Long-term AVG & & 2013 & 2014 & Long-term AVG \\
\hline Jan & 5.6 & 28.2 & 14.0 & & 25 & 28 & 22 \\
Feb & 6.6 & 9.4 & 11.4 & 28 & 15 & 25 \\
Mar & 2.5 & 28.4 & 18.0 & 32 & 28 & 25 \\
Apr & 17.3 & 16.3 & 30.5 & 37 & 38 & 41 \\
May & 80.5 & 41.7 & 65.5 & 52 & 48 & 50 \\
Jun & 96.3 & 62.2 & 79.2 & 58 & 55 & 58 \\
Jul & 42.9 & 34.5 & 42.4 & 68 & 68 & 66 \\
Aug & 24.6 & 159.3 & 41.7 & 59 & 65 & 65 \\
Sep & 96.5 & 59.4 & 35.8 & 60 & 55 & 55 \\
Oct & 39.9 & 16.5 & 23.1 & 46 & 50 & 45 \\
Nov & 3.8 & 11.4 & 14.5 & 33 & 27 & 33 \\
Dec & 12.4 & 8.9 & 13.7 & 21 & 25 & 25 \\
\hline
\end{tabular}




\subsection{Grain yield data collection}

Plants were harvested when grains were completely matured (in early- to mid-July) using a Wintersteiger plot combine (Wintersteiger Inc., Salt Lake City, UT). After harvesting, grains were weighed. Grain yield was reported based on $6 \%(\mathrm{w} / \mathrm{w})$ moisture content.

\subsection{Energy balance}

Energy balance was evaluated according to the Process Analysis Methodology [23], accounting for energy input of machinery (manufacturer and operation, fuel, and lubricants), fertilizer, and pesticides. Inputs of machines, fertilizers, and pesticides were converted to energy equivalents using standard coefficients (Table 2). Among the available coefficients, we selected the most up-to-date values that have been used by other researchers in similar environments. Seed for planting was not included as energy input; instead, it was subtracted from the harvested grain yield. Neither environmental inputs (e.g. solar radiation, precipitation, soil nutrients) nor labor inputs were considered in the energy input calculation, because labor usually has an insignificant share in the total energy inputs of the mechanized farming systems [14]. Since this study only considers in-farm energy flow, energy costs for delivering the product to off-farm location and storage were not considered (the energy costs for delivery and storage are usually included in biorefinery logistics). The total energy input per hectare was calculated by summing up the energy equivalents of all inputs.

Energy output was determined by multiplying grain yield with grain high heating value $\left(26.5 \mathrm{MJ} \mathrm{kg}^{-1}\right)$ which was measured using a bomb calorimeter. Crop residue did not get an allowance as energy output since it was returned to the soil. Based on the energy inputs and outputs, the following energy balance indices were calculated:

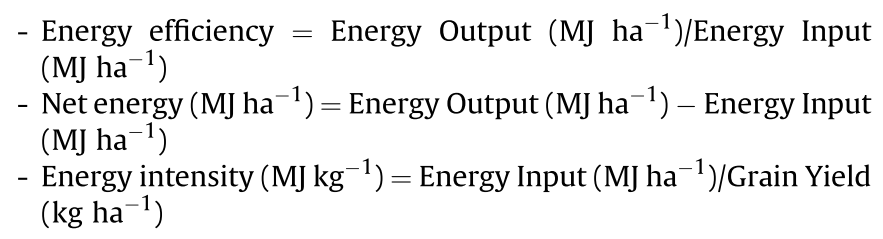

\section{4. $\mathrm{CO}_{2}$ emission}

Proper emission factors (which refers to a typical quantity of GHGs released to the atmosphere per unit of the activity) for each input and farm operation was used to determine GHG emissions

Table 2

Energy coefficients and GHG emissions factor used in this study.

\begin{tabular}{lccll}
\hline Input & $\begin{array}{l}\text { Energy } \\
\text { coefficient } \\
\left(\mathrm{MJ} \mathrm{input}^{-1}\right)\end{array}$ & Reference & $\begin{array}{l}\text { GHG } \\
\text { emission factor } \\
\left(\mathrm{kg} \mathrm{C} \mathrm{eq} \mathrm{input}^{-1}\right)\end{array}$ & Reference \\
\hline Input & & & & \\
$\begin{array}{l}\left.\text { Glyphosate (L a.i. }{ }^{\mathrm{a}}\right) \\
\text { Nitrogen (kg N) }\end{array}$ & 356 & {$[23]$} & 9.1 & {$[22]$} \\
Operation (ha) ${ }^{\mathrm{b}}$ & 56.7 & {$[23]$} & 1.3 & {$[22]$} \\
Tillage & 244.7 & {$[14]$} & 7.9 & {$[22]$} \\
Air seeder & 408.0 & {$[23]$} & 3.8 & {$[22]$} \\
Pesticide sprayer & 126.0 & {$[23]$} & 1.4 & {$[22]$} \\
Fertilizer spreader & 91.0 & {$[23]$} & 7.6 & {$[24]$} \\
Combine harvester & 350.0 & {$[23]$} & 10.0 & \\
\hline
\end{tabular}

a Active ingredient.

b Including energy for manufacturing, operating, maintenance, fuel and lubrication. per hectare $\left(\mathrm{kg} \mathrm{C}\right.$ eq ha ${ }^{-1}$ ) (Table 2 ). In these emission factors, emissions of important GHG associated with agricultural activities (i.e., carbon dioxide $\left(\mathrm{CO}_{2}\right)$, nitrous oxide $\left(\mathrm{N}_{2} \mathrm{O}\right)$ and methane $\left(\mathrm{CH}_{4}\right)$ ) are converted to $\mathrm{C}$ eq using the GWP (global warming potential) of each gas, which refers to the relative contribution of a gas to the greenhouse effect with a time span of 100 years [25]. This approach helped us to assess the real $C$ cost of production system by converting the diverse units into $\mathrm{kg} \mathrm{C}$ eq emission.

\subsection{Data analysis}

Data of energy output and energy balance indices (averaged over two years) as influenced by tillage system and nitrogen fertilization were subject to ANOVA using PROC GLM of SAS. Fisher's least significant difference test (LSD) at $P<0.05$ was employed to separate the means.

\section{Results}

\subsection{Energy input}

The influence of tillage system and nitrogen fertilizer on camelina energy input is shown in Fig. 1. No considerable differences were found between tillage systems. Averaged across nitrogen treatments, 4138 and $3927 \mathrm{MJ} \mathrm{ha}^{-1}$ non-renewable energy was used for camelina production in CT and NT, respectively Fig. 1.

Nitrogen fertilizer greatly influenced total energy used for production of camelina. With the $\mathrm{N}$ input level increased from control treatment $\left(0 \mathrm{~kg} \mathrm{~N} \mathrm{ha}^{-1}\right)$ to 45 and $90 \mathrm{~kg} \mathrm{~N} \mathrm{ha}^{-1}$, energy input for camelina production increased by 186 and 365\% compared to $1420 \mathrm{MJ} \mathrm{ha}^{-1}$ in the control treatment (Fig. 1). Nitrogen fertilizer had the biggest share in total energy input of camelina followed by machinery (Fig. 1). Nitrogen input accounts for $61-76 \%$ of the total energy used for camelina production at 45 and $90 \mathrm{~kg} \mathrm{~N} \mathrm{ha}^{-1}$ input rates, respectively.

\subsection{Energy output}

Analysis of variance showed that energy output of camelina was significantly affected by nitrogen fertilizer, but not by tillage system (Table 3). Irrespective to the tillage method, total energy output of camelina in $0 \mathrm{~N}$ treatment was $14,805 \mathrm{MJ} \mathrm{ha}^{-1}$ (Fig. 2). When camelina received 45 and $90 \mathrm{~kg} \mathrm{~N} \mathrm{ha}^{-1}$, its energy output increased by 21 and $64 \%$, respectively.

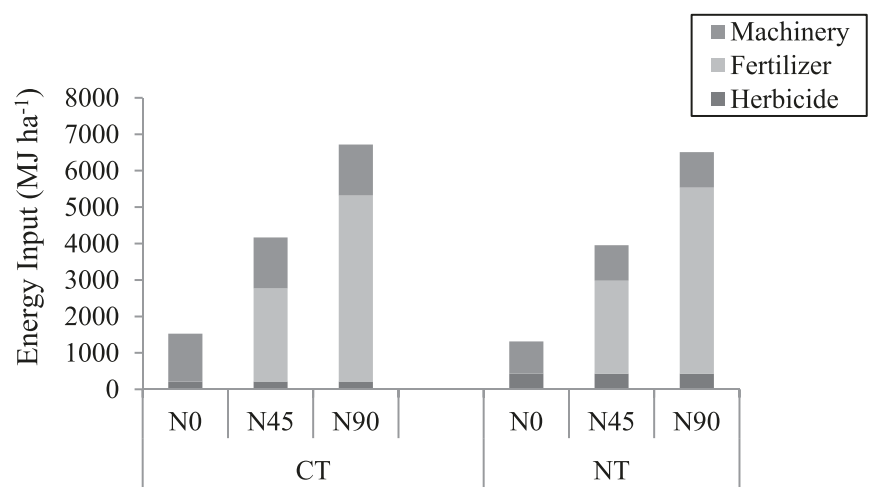

Fig. 1. Camelina energy input and its constituents as influenced by tillage method and nitrogen fertilizer rate. CT: conventional tillage; NT: no tillage. N0: $0 \mathrm{~kg} \mathrm{~N} \mathrm{ha}^{-1}$; N45: $45 \mathrm{~kg} \mathrm{~N} \mathrm{ha}{ }^{-1}$; 900 : $90 \mathrm{~kg} \mathrm{~N} \mathrm{ha}^{-1}$ 


\subsection{Energy indices}

Tillage method did not influence camelina energetic indices (Table 3). Averaged over all experimental treatments, $14,945 \mathrm{MJ} \mathrm{ha}^{-1}$ net energy was obtained from camelina in this study (Fig. 3). Net energy followed a progressive increasing trend in response to the application of $\mathrm{N}$ fertilizer; however, no significant differences were found between the $\mathrm{N}$ treatments in this regard (Fig. 3). The positive impact of nitrogen in enhancing the energy output was completely offset by greater energy input associated with $\mathrm{N}$ fertilization. An opposite trend was observed for energy efficiency, where the highest energy efficiency (10.4) was obtained at $0 \mathrm{~kg} \mathrm{~N} \mathrm{ha}^{-1}$ (Fig. 4). Energy efficiency declined from 10.4 to 4.4 when $45 \mathrm{~kg} \mathrm{~N} \mathrm{ha}^{-1}$ was applied, and further declined to 3.7 when $90 \mathrm{~kg} \mathrm{~N} \mathrm{ha}^{-1}$ was added. It clearly shows the more external nitrogen was applied the less efficiency of input energy was obtained. Energy intensity, the amount of non-renewable energy used to produce one unit $(\mathrm{kg})$ of grain, also responded significantly to the application of nitrogen (Table 3; Fig. 5). When no nitrogen was applied, $2.7 \mathrm{MJ}$ non-renewable energy was required to produce one $\mathrm{kg}$ camelina grain. This value reached 6.3 and $7.7 \mathrm{MJ}$ when 45 and $90 \mathrm{~kg} \mathrm{~N} \mathrm{ha}^{-1}$ were consumed.

\subsection{GHG emissions}

Data of GHG emissions are shown in Figs. 6 and 7. Averaged over tillage and fertilizer treatments, $95.6 \mathrm{~kg} \mathrm{C}$ eq ha $^{-1}$ was emitted due to camelina biofuel feedstock production. Implementation of NT resulted in 8\% lower GHG emissions compared with CT (Fig. 6). Unlike the effect of tillage method, nitrogen fertilization greatly influenced GHG emissions. When no external nitrogen was applied, GHG emissions were $32.1 \mathrm{~kg} \mathrm{C}$ eq ha ${ }^{-1}$ (averaged over two tillage systems). With the application of 45 and $90 \mathrm{~kg} \mathrm{~N} \mathrm{ha}^{-1}$, GHG emissions increased 206 and $389 \%$ compared to the control treatment, respectively. Fig. 7 shows the changes in GHG emission based on net energy gained under the influence of tillage method and nitrogen fertilizer. When 0 and $45 \mathrm{~kg} \mathrm{~N}^{-1}$ was applied, GHG emissions in CT plots were greater than those in NT plots. However, when $90 \mathrm{~kg} \mathrm{ha}^{-1} \mathrm{~N}$ was used, GHG emission per each unit of net energy (MJ) was higher in NT than in CT.

\section{Discussion}

Under the condition of this study, camelina production required $4032 \mathrm{MJ} \mathrm{ha}^{-1}$ energy input and emitted $95.6 \mathrm{~kg} \mathrm{C}^{\mathrm{eq} \mathrm{ha}}{ }^{-1} \mathrm{GHG}$ (averaged over tillage and $\mathrm{N}$ treatments). One of the most important factors determining the suitability of a bioenergy crop is the amount of input energy [26] and the quantity of GHG emitted during the production process of the crop [27]. Compared with the energy input used for production of other biofuel crops such as rapeseed, camelina required less energy input in this dryland

\section{Table 3}

Analysis of variance for the effect of tillage method and nitrogen fertilizer rate on energy output and energy balance indicators of camelina (combined data of 2013 and 2014 were subject to analysis).

\begin{tabular}{lllll}
\hline SOV & $\begin{array}{l}\text { Energy } \\
\text { output }\end{array}$ & $\begin{array}{l}\text { Net } \\
\text { energy }\end{array}$ & $\begin{array}{l}\text { Energy } \\
\text { efficiency }\end{array}$ & $\begin{array}{l}\text { Energy } \\
\text { intensity }\end{array}$ \\
\hline Tillage system & NS & NS & NS & NS \\
Nitrogen & $* *$ & NS & $* *$ & $* *$ \\
Tillage $\times$ Nitrogen & NS & NS & NS & NS \\
CV & 18.9 & 19.8 & 21.9 & 11.2 \\
\hline
\end{tabular}

** Significant at $\mathrm{P}<0.01$

NS non-significant.

$\mathrm{CV}$ : coefficient of variation.

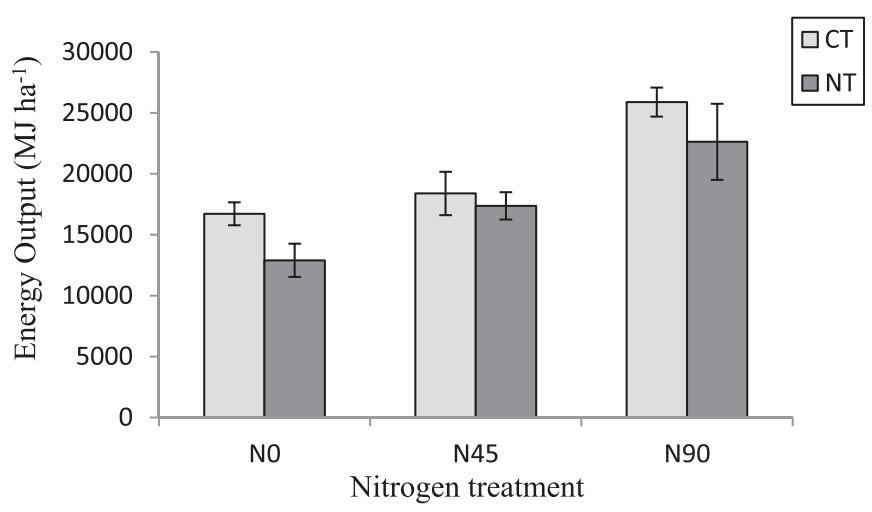

Fig. 2. Camelina energy output as influenced by tillage method and nitrogen fertilizer rate. Vertical bars are standard error $(\mathrm{n}=4)$. CT: conventional tillage; NT: no tillage. N0: $0 \mathrm{~kg} \mathrm{~N} \mathrm{ha}^{-1}$; N45: $45 \mathrm{~kg} \mathrm{~N} \mathrm{ha}^{-1}$; N90: $90 \mathrm{~kg} \mathrm{~N} \mathrm{ha}^{-1}$

farming system. For instance, Fore et al. [28] estimated that production of rapeseed in the U.S. upper Midwest requires $9506 \mathrm{MJ} \mathrm{ha}^{-1}$ energy input. Jankowski et al. [29] found that production of winter rapeseed in Poland requires of 26,290 $\mathrm{MJ} \mathrm{ha}^{-1}$ and Unakitan et al. [30] reported 18,297 $\mathrm{MJ} \mathrm{ha}^{-1}$ as energy input requirement of rapeseed in Turkey. Moreover, GHG emissions from camelina field seems lower compared with other suitable biofuel crops for this region such as canola. The GHG emissions for production of canola has been reported in the range of 207-389 kg C eq ha ${ }^{-1}$ [31], 442-469 kg C eq ha ${ }^{-1}$ [27], and $278 \pm 35 \mathrm{~kg} \mathrm{C}$ eq ha $^{-1}$ [32]. A lower estimation of GHG emissions from camelina in the current study could mainly be attributed to low energy input used for camelina production in this region as well as the exclusion of irrigation which possess a great portion in total GHG emissions in irrigated farms.

On the other hand, camelina energy output, net energy, energy efficiency and energy intensity were 18,987 MJ ha ${ }^{-1}$, $14,945 \mathrm{MJ} \mathrm{ha}^{-1}, 6.1$, and $5.6 \mathrm{MJ} \mathrm{kg}^{-1}$, respectively (averaged over tillage and $\mathrm{N}$ treatments). In an earlier effort, we estimated energy output, net energy, and energy efficiency of camelina in dryland farming system of central Montana as 24,022 MJ ha ${ }^{-1}$, $18,283 \mathrm{MJ} \mathrm{ha}^{-1}$, and 4.2 , respectively (averaged over three experimental years) [7]. Compared with other biofuel crops such as canola [28-30], energy output of camelina was lower due to low yield of the crop in this dryland system. Lewandowski and Schmidt

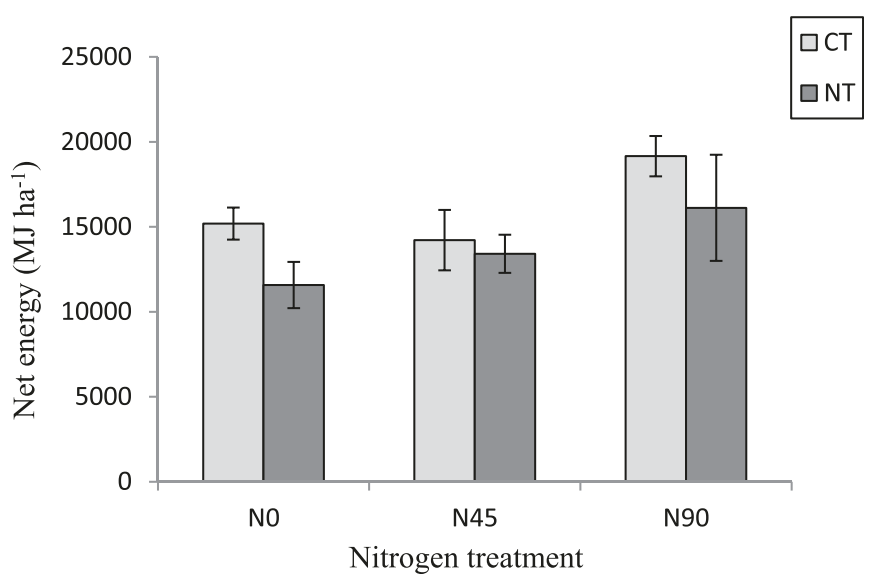

Fig. 3. Camelina net energy output as influenced by tillage method and nitrogen fertilizer rate. Vertical bars are standard error $(n=4)$. CT: conventional tillage; NT: no tillage. N0: $0 \mathrm{~kg} \mathrm{~N}^{-1}$; N45: $45 \mathrm{~kg} \mathrm{~N} \mathrm{ha}^{-1}$; N90: $90 \mathrm{~kg} \mathrm{~N} \mathrm{ha}^{-1}$ 


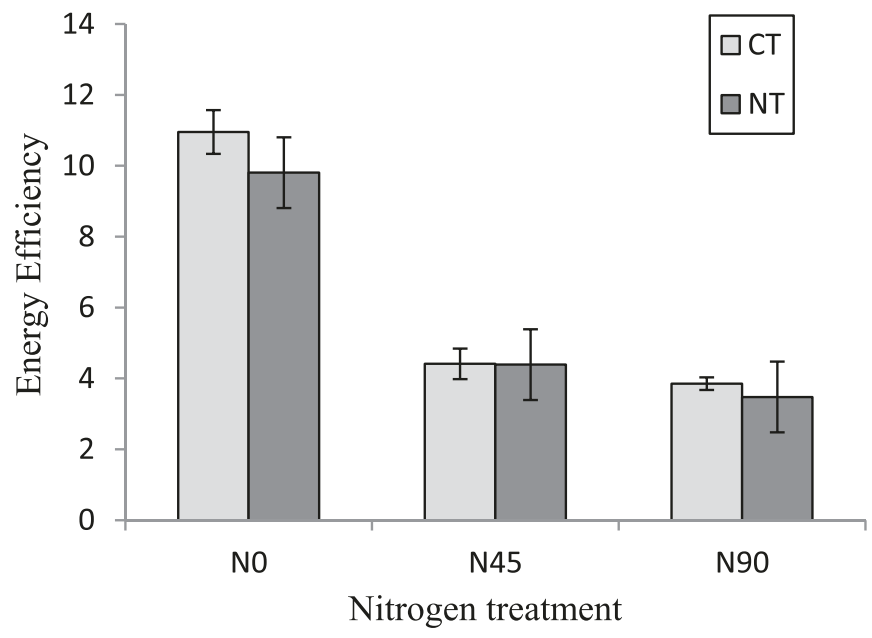

Fig. 4. Camelina energy efficiency as influenced by tillage method and nitrogen fertilizer rate. Vertical bars are standard error $(n=4)$. CT: conventional tillage; NT: no tillage. N0: $0 \mathrm{~kg} \mathrm{~N} \mathrm{ha}^{-1}$; N45: $45 \mathrm{~kg} \mathrm{~N} \mathrm{ha}^{-1}$; N90: $90 \mathrm{~kg} \mathrm{~N} \mathrm{ha}^{-1}$

[26] stated that suitable energy crops yield significantly more energy than that used to grow them. In this study, camelina net energy output was $14,945 \mathrm{MJ} \mathrm{ha}^{-1}$, reflecting the potential of this crop for energy farming.

It should be noticed that many other biofuel crops such as corn or soybean has low chance to grow in this semi-arid northern environment and our field studies show that canola usually yields less than camelina in this environment. Thus, it seems that camelina has higher potential for biofuel feedstock production in the NGP dryland farming systems when compared to other biofuel crops.

It's worth mentioning that there was a gap between camelina yield in this study and average yield reported for this crop in other regions of Montana [4]. Development of new and high yielding cultivars along with the improvement of the agronomic practices will likely improve camelina yields which in turn will also enhance its energy performance in this dryland farming system.

Energy input and GHG emissions of camelina were slightly lower in NT than that in CT which is consistent with reports by other researchers [11,33]. Arvidsson [34] reported that implementation of NT in wheat production resulted in 1000-2200 MJ ha ${ }^{-1}$ (depending on the soil texture) savings of

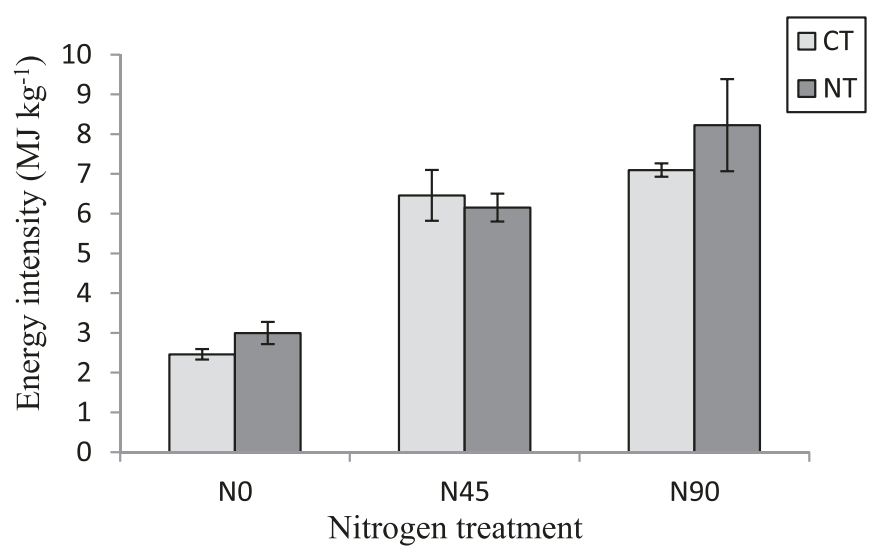

Fig. 5. Camelina energy intensity as influenced by tillage method and nitrogen fertilizer rate. Vertical bars are standard error $(n=4)$. CT: conventional tillage; NT: no tillage. N0: $0 \mathrm{~kg} \mathrm{~N}^{-1}$; N45: $45 \mathrm{~kg} \mathrm{~N} \mathrm{ha}^{-1}$; N90: $90 \mathrm{~kg} \mathrm{~N}^{-1}$

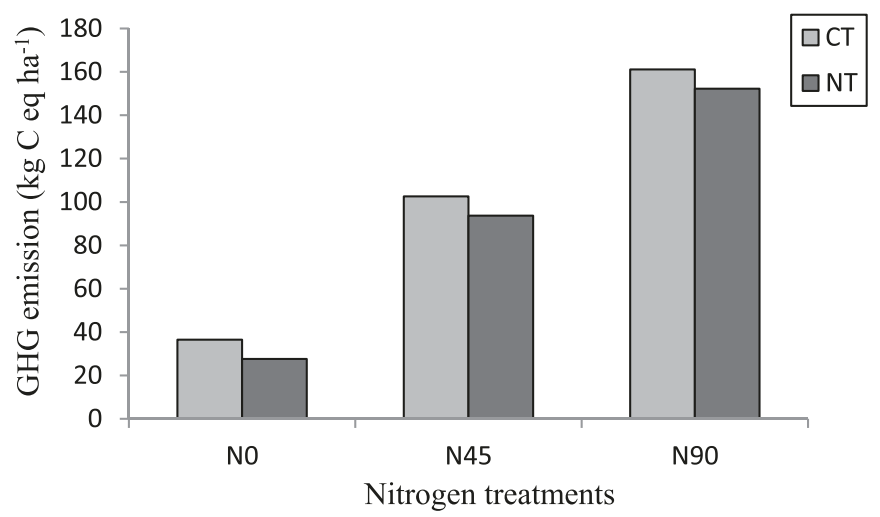

Fig. 6. GHG emission ( $\mathrm{kg} \mathrm{C}$ eq ha ${ }^{-1}$ ) from camelina field as influenced by tillage method and nitrogen fertilizer rate. CT: conventional tillage; NT: no tillage. NO: $0 \mathrm{~kg} \mathrm{~N} \mathrm{ha}^{-1}$; N45: $45 \mathrm{~kg} \mathrm{~N} \mathrm{ha}^{-1}$; N90: $90 \mathrm{~kg} \mathrm{~N}^{-1}$

energy input compared with CT in Sweden. Similarly, Rathke et al. [35] reported $1380 \mathrm{MJ} \mathrm{ha}^{-1}$ energy savings when moldboard plowing was replaced with NT in a maize-soybean production system of eastern Nebraska.

Not a significant difference between NT and CT in terms of energy input and GHG emissions in the current study is primarily due to small contribution of machinery in total energy input of camelina in such low-input dryland farming system. Generally, in dryland farming system tillage intensity is minimized even when $C T$ is practiced in order to reduce the risk of soil erosion and loss of soil stored moisture. Consequently, adoption of NT system did not considerably influence energy input and GHG emissions compared to CT. Furthermore, lower energy input and GHG emissions attributed to machinery and fossil fuel spent in NT was compromised with additional herbicide used in this system for weed control. The comparable and similar performance of camelina in NT and CT systems is positive. This result reveals that in addition to the agronomic and economic benefits of NT in this dryland ecosystem such as soil protection and soil water conservation [36], no unfavorable impacts on camelina energy balance and GHG emissions was associated with this type of tillage. Therefore, implementation of NT could be strongly recommended for camelina production in this region.

Unlike tillage system, nitrogen fertilizer greatly influenced energy balance and GHG emissions for camelina production. When nitrogen fertilizer was used, energy input and GHG emissions

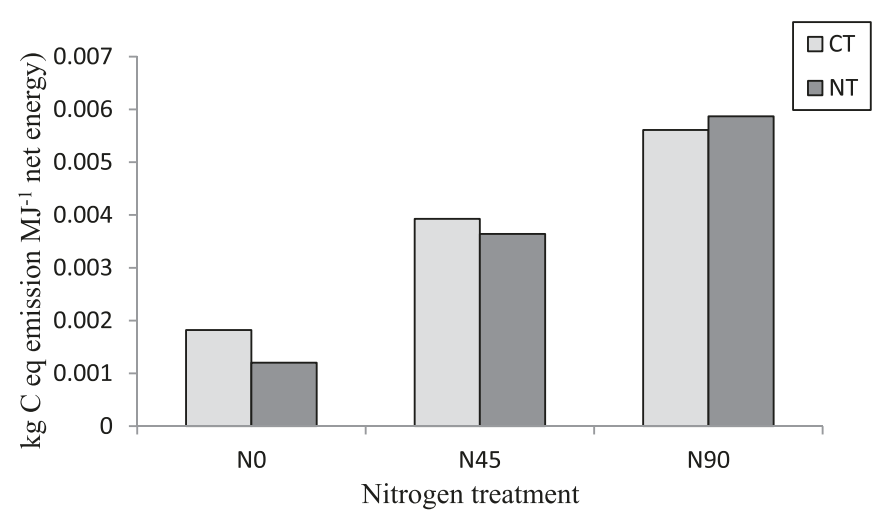

Fig. 7. GHG emission per MJ of net energy ( $\mathrm{kg} \mathrm{C}$ eq $\mathrm{MJ}^{-1}$ net energy) produced in camelina field under the influence of tillage method and nitrogen fertilizer rate. $\mathrm{CT}$ : conventional tillage; NT: no tillage. N0: $0 \mathrm{~kg} \mathrm{~N} \mathrm{ha}^{-1}$; N45: $45 \mathrm{~kg} \mathrm{~N}^{\mathrm{Na}} \mathrm{ha}^{-1}$ N90: $90 \mathrm{~kg} \mathrm{~N} \mathrm{ha}^{-1}$ 
increased considerably. The production of nitrogen fertilizer is a very energy-demanding process, and thus generates considerable GHG emissions [37]. Results showed that when 45 and $90 \mathrm{~kg} \mathrm{~N} \mathrm{ha}^{-1}$ was used, $61-76 \%$ of the total energy used for camelina production was attributed to the application of this input (irrespective to tillage method). Our results agreed with most previous studies which showed considerable constitution of nitrogen fertilizer in total energy input for production of different agronomic crops [9-11,14].

Application of nitrogen fertilizer also significantly influenced energy indices of camelina. Applications of 45 and $90 \mathrm{~kg} \mathrm{~N} \mathrm{ha}{ }^{-1}$ increased camelina gross output energy by 21 and 64\%, whereas net energy remained stable in response to nitrogen fertilization. In fact, the positive effect of nitrogen to increase energy output was completely offset by greater energy input associated with this input. Nitrogen fertilization also adversely affected energy efficiency and energy intensity (Fig. 5). These results show that nitrogen is not used effectively in the camelina production system and not sufficient outcome was gained per unit of used fertilizer. In this region, urea, the main source of $\mathrm{N}$ fertilizer, is top-dressed in the spring. This practice resulted in considerable nitrogen losses through volatilization and denitrification. Engel et al. [38] reported that ammonia volatilization can exceed $40 \%$ of the applied $\mathrm{N}$ in this region. Being a very $\mathrm{C}$-intensive input, optimization of nitrogen fertilization and minimizing losses are prudent to enhance the ecological sustainability of the farming system in this region. Inclusion of pulse crops in the cropping system, integration of crop-livestock production system, refinement of the nitrogen fertilization strategies (type of fertilizer, timing and placement method) are among the useful approaches to improve NUE (Nitrogen Use Efficiency) in this region. Enhancement of NUE will improve energy efficiency, reduce the environmental emissions, and curb economic costs, which ultimately will increase the sustainability of the farming system.

\section{Conclusion}

Camelina production in dryland farming system at central Montana resulted in $14,945 \mathrm{MJ}$ net energy ha ${ }^{-1}$ and $95.6 \mathrm{~kg} \mathrm{C}$ eq ha ${ }^{-1}$ GHG emissions (averaged over tillage and $\mathrm{N}$ treatments). Due to similar energetic performance and gas emissions of camelina in NT and CT practices, adoption of NT is desirable for camelina production in this region. According to the results of this study, nitrogen plays a crucial role in determining energy efficiency and GHG emissions of camelina. Application of nitrogen fertilizer did not influence net energy, but lowered energy efficiency and considerably increased GHG emissions. Potentially, it is possible to improve energy efficiency and reduce GHG emissions of camelina through the optimization of agronomic practices and utilization of modern high yielding cultivars. Our results showed that improvement of nitrogen use efficiency is crucial to improve energy balance and ecological sustainability of camelina and has the highest priority to achieve the above mentioned goals. The results of this study help us toward identifying and modifying the high energy-demanding and C-intensive inputs and operations for the camelina biofeedstock production in this dryland environment. It is expected the information obtained from this study is applicable to cemelina producers in other regions to improve energy balance in cemelina production.

\section{Acknowledgment}

The authors like to acknowledge Sally Dahlhausen for the technical support in the field study and sample processing. The funding support for this study came from the Montana Fertilizer Tax, Montana Experiment Station, and a grant from the USDA-BRDI program (Grant\#2012-10006-20230).

\section{References}

[1] Shonnard DR, Williams L, Kalnes TN. Camelina-derived jet fuel and diesel: sustainable advanced biofuels. Environ Prog Sustain Energy 2010;29:382-92.

[2] Chen C, Bekkerman A, Keshavarz Afshar R, Neil K. Intensification of dryland cropping systems for bio-feedstock production: evaluation of agronomic and economic benefits of camelina sativa. Ind Crop Prod 2015;71:114-21.

[3] Vollmann J, Moritz T, Kargl C, Baumgartner S, Wagentristl H. Agronomic evaluation of $C$. sativa genotypes selected for seed quality characteristics. Ind Crop Prod 2007;26:270-7.

[4] McVay KA, Khan QA. Camelina yield response to different plant populations under dryland conditions. Agron J 2011;103:1265-9.

[5] Brian J, Krohn MF. A life cycle assessment of biodiesel derived from the "niche filling" energy crop camelina in the USA. Appl Energy 2012;92:92-8.

[6] Li X, Mupondwa E. Life cycle assessment of camelina oil derived biodiesel and jet fuel in the Canadian prairies. Sci Total Environ 2014;481:17-26.

[7] Keshavarz-Afshar R, Chen C. Intensification of dryland cropping systems for bio-feedstock production: energy analysis of camelina. Bioenergy Res 2015. http://dx.doi.org/10.1007/s12155-015-9644-8.

[8] Malhi SS, Johnson EN, Hall LM, May WE, Phelps S, Nybo B. Effect of nitrogen fertilizer application on seed yield, $\mathrm{N}$ uptake, and seed quality of Camelina sativa. Can J Soil Sci 2014;94:35-47.

[9] McLaughlin NB, Hiba A, Wall GJ, King DJ. Comparison of energy inputs for inorganic fertilizer and manure based corn production. Can Agric Eng 2000;42:9-18.

[10] Hülsbergen K, Feil B, Diepenbrock W. Rates of nitrogen application required to achieve maximum energy efficiency for various crops: results of a long-term experiment. Field Crop Res 2002;77:61-76.

[11] Rathke GW, Diepenbrock W. Energy balance of winter oilseed rape (Brassica napus L.) cropping as related to nitrogen supply and preceding crop. Eur J Agron 2006;24:35-44.

[12] Hernanz JL, Sánchez-Girón V, Navarrete L, Sánchez MJ. Long-term (1983-2012) assessment of three tillage systems on the energy use efficiency, crop production and seeding emergence in a rain fed cereal monoculture in semiarid conditions in central Spain. Field Crop Res 2014;166:26-37.

[13] Borin M, Merini C, Sartori L. Effects of tillage systems on energy and carbon balance in north-eastern Italy. Soil Tillage Res 1997;40:209-26.

[14] Zentner RP, Lafond GP, Derksen DA, Nagy CN, Wall DD, May WE. Effects of tillage method and crop rotation on non-renewable energy use efficiency for a thin black chernozem in the Canadian prairies. Soil Tillage Res 2004;77:125-36.

[15] Šarauskis E, Buragiené S, Masilionytè L, Romaneckas K, Avižienytè D, Sakalauskas A. Energy balance, costs and $\mathrm{CO}_{2}$ analysis of tillage technologies in maize cultivation. Energy 2014;69:227-35.

[16] Bonari E, Mazzoneini M, Peruzzi A. Effects of conventional and minimum tillage on winter oil seed rape. Soil Tillage Res 1995;33:91-108.

[17] Cantero-Martínez C, Angas P, Lampurlanés J. Growth, yield and water productivity of barley Hordeum vulgare L. affected by tillage and $\mathrm{N}$ fertilization in Mediterranean semiarid, rainfed conditions of Spain. Field Crop Res 2003;84: $341-57$.

[18] López-Bellido RJ, López-Bellido L, Castillo JE, López-Bellido FJ. Chickpea response to tillage and soil residual nitrogenina continuous rotation with wheat II. Soil nitrate, N uptake and influence on wheat yield. Field Crop Res 2004;88:201-10.

[19] López-Bellido RJ, López-Bellido L, Castillo JE, López-Bellido FJ. Sunflower response to tillage and soil residual nitrogen in a wheat-sunflower rotation under rainfed Mediterranean conditions. Crop Pasture Sci 2002;53:1027-33.

[20] Yousefi M, Khoramivafa M, Mondani F. Integrated evaluation of energy use greenhouse gas emissions and global warming potential for sugar beet (Beta vulgaris) agroecosystems in Iran. Atmos Environ 2014;92:501-5.

[21] Dalgaard T, Halberg N, Porter JR. A model for fossil energy use in Danish agriculture used to compare organic and conventional farming. Agric Ecosyst Environ 2001;87:51-65.

[22] Lal R. Carbon emission from farm operations. Environ Int 2004;30:981-90.

[23] Burgess MH, Miller PR, Jones CA. Pulse crops improve energy intensity and productivity of cereal production in Montana, USA. J Sustain Agric 2012;36: 699-718.

[24] Pathak H, Wassmann R. Introducing greenhouse gas mitigation as a development objective in rice-based agriculture: I. Generation of technical coefficients. Agric Syst 2007;94:807-25.

[25] IPCC. Climate change. Impacts adaptation and vulnerability. In: Parry ML, Canziani OF, Palutikof JP, van der Linden PJ, Hanson CE, editors. Contribution of working group II to the fourth assessment report of the intergovernmental panel on climate change2007. Cambridge UK: Cambridge University Press; 2007. p. 976.

[26] Lewandowski I, Schmidt U. Nitrogen, energy and land use efficiencies of miscanthus, reed canary grass and triticale as determined by the boundary line approach. Agric Ecosyst Environ 2006;112:335-46.

[27] Williams AG, Audsley E, Sandars DL. Determining the environmental burdens and resource use in the production of agricultural and horticultural commodities. Main Report. Defra Research Project IS0205. Bedford: Cranfield University and Defra; 2006.

[28] Fore SR, Porter P, Lazarus W. Net energy balance of small-scale on-farm biodiesel production from canola and soybean. Biomass Bioenergy 2011;35: 2234-44. 
[29] Jankowski KJ, Budzyński WS, Kijewski Ł. An analysis of energy efficiency in the production of oilseed crops of the family Brassicaceae in Poland. Energy 2015;8:674-81.

[30] Unakitan G, Hurma H, Yilmaz F. An analysis of energy use efficiency of canola production in Turkey. Energy 2010;35:3623-7.

[31] Soltani A, Maleki MHM, Zeinali E. Optimal crop management can reduce energy use and greenhouse gases emissions in rainfed canola production. IJPP 2014;8:587-604.

[32] Neufeldt N, Schäfer M. Mitigation strategies for greenhouse gas emissions from agriculture using a regional economic-ecosystem model. Agric Ecosyst Environ 2008;123:305-16.

[33] Boehmel C, Lewandowski I, Claupein W. Comparing annual and perennia energy cropping systems with different management intensities. Agric Syst 2008;96:224-36.
[34] Arvidsson J. Energy use efficiency in different tillage systems for winter wheat on a clay and silt loam in Sweden. Eur J Agron 2010;33:250-6.

[35] Rathke GW, Wienhold BJ, Wilhelm WW, Diepenbrock W. Tillage and rotation effect on corn-soybean energy balances in eastern Nebraska. Soil Tillage Res 2007;97:60-70.

[36] Hansen NC, Allen BL, Baumhardt RL, Lyon DJ. Research achievements and adoption of no-till, dryland cropping in the semi-arid US great plains. Field Crop Res 2012;132:196-203.

[37] Kongshaug G. Energy consumption and greenhouse Gas emissions in fertilizer production. IFA technical Conference, Marrakech, Morocco, 28 September-1 October, 1998. 1998. p. 18. pp.

[38] Engel R, Jones C, Wallander R. Ammonia volatilization from urea and mitigation by NBPT following surface application to clod soils. Soil Sci Soc Am J 2011;75:2348-57. 